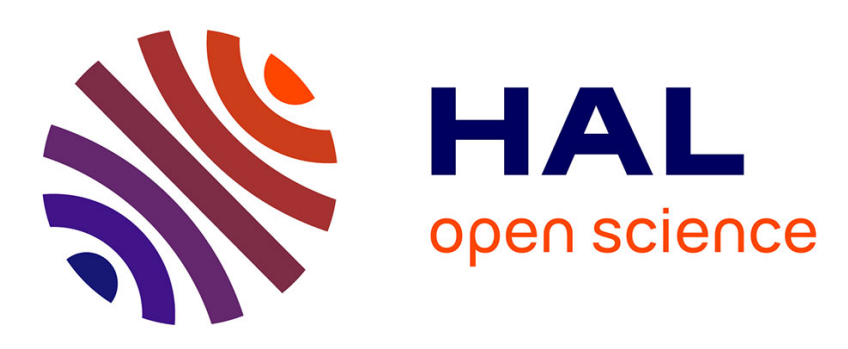

\title{
Effects of HCV co-infection on apoptosis of CD4+ T cells in HIV-positive patients
}

Christian Körner, Benjamin Krämer, Daniela Schulte, Martin Coenen, Stefan

Mauss, Gerd Fätkenheuer, Johannes Oldenburg, Jacob Nattermann, Jürgen Rockstroh, Ulrich Spengler

\section{To cite this version:}

Christian Körner, Benjamin Krämer, Daniela Schulte, Martin Coenen, Stefan Mauss, et al.. Effects of HCV co-infection on apoptosis of CD4+ T cells in HIV-positive patients. Clinical Science, 2009, 116 (12), pp.861-870. 10.1042/CS20080532 . hal-00483309

\section{HAL Id: hal-00483309 \\ https://hal.science/hal-00483309}

Submitted on 14 May 2010

HAL is a multi-disciplinary open access archive for the deposit and dissemination of scientific research documents, whether they are published or not. The documents may come from teaching and research institutions in France or abroad, or from public or private research centers.
L'archive ouverte pluridisciplinaire HAL, est destinée au dépôt et à la diffusion de documents scientifiques de niveau recherche, publiés ou non, émanant des établissements d'enseignement et de recherche français ou étrangers, des laboratoires publics ou privés. 


\section{Effects of $\mathrm{HCV}$ co-infection on apoptosis of $\mathrm{CD4}^{+} \mathrm{T}$ cells in $\mathrm{HIV}$-positive patients}

Christian Körner ${ }^{1)}$, Benjamin Krämer ${ }^{1)}$, Daniela Schulte ${ }^{1)}$, Martin Coenen ${ }^{1)}$, Stefan Mauss ${ }^{2)}$,

Gerd Fätkenheuer ${ }^{3)}$, Johannes Oldenburg ${ }^{4)}$, Jacob Nattermann ${ }^{1)}$, Jürgen K. Rockstroh ${ }^{1)}$, Ulrich Spengler ${ }^{1)}$

1) Department of Internal Medicine I, University of Bonn, Germany Sigmund-Freud-Str. 25

53127 Bonn, Germany

2) Center for HIV and Hepatogastroenterology, Düsseldorf, Germany

3) Department of Internal Medicine I, University of Cologne, Germany

4) Department of Experimental Hematology and Transfusion Medicine, University of Bonn, Germany

Keywords: HIV-1, apoptosis, $\mathrm{CD}^{+}{ }^{+} \mathrm{T}$ cells, Hepatitis C virus, HAART, protease inhibitors

Send correspondence to:

Christian Körner

Department of Internal Medicine I

University of Bonn

Sigmund-Freud-Str. 25

53127 Bonn, Germany

Email: christian.koerner@ukb.uni-bonn.de

Telephone: 0049-228-28715383

Fax: 0049-228-28714611 


\begin{abstract}
Background: Apoptosis importantly contributes to loss of $\mathrm{CD}^{+} \mathrm{T}$ cells in $\mathrm{HIV}$ infection, and modification of their apoptosis may explain why HIV/HCV-co-infected patients are more likely to die from liver-related causes, while effects of HCV on HIV infection remain unclear. Methods: We studied in a cross-sectional and serial analysis spontaneous ex vivo CD4 $4^{+} \mathrm{T}$ cell apoptosis in HIV/HCV-co-infected and HIV-mono-infected patients before and after HAART. Apoptosis of peripheral blood $\mathrm{CD}^{+} \mathrm{T}$ cells was measured by both, a Poly [1] polymerase [1] and TdT-mediated dUTP-FITC nick end labelling (TUNEL) assay to detect cells with irreversible apoptosis.

Results: While hepatitis $\mathrm{C}$ alone did not increase $\mathrm{CD}^{+} \mathrm{T}$ cell apoptosis, $\mathrm{HCV}$ co-infection disproportionately increased elevated rates of apoptosis in $\mathrm{CD}^{+} \mathrm{T}$ cells from untreated HIV-positive patients. Increased $\mathrm{CD}^{+} \mathrm{T}$ cell apoptosis was closely correlated to HIV but not HCV viral loads. Under HAART increased rates of $\mathrm{CD}^{+} \mathrm{T}$ cell apoptosis rapidly decreased both in HIV-monoinfected and HIV/HCV-co-infected patients, without any significant difference in apoptosis rates between the two patients groups after 4 weeks of therapy. Nevertheless residual CD $4^{+} \mathrm{T}$ cell apoptosis did not reach the normal levels seen in healthy controls and remained higher in HIV patients receiving protease inhibitors than in patients with other antiretroviral regimens.

Conclusions: Our results suggest that $\mathrm{HCV}$ co-infection sensitizes $\mathrm{CD} 4^{+} \mathrm{T}$ cells towards apoptosis in untreated HIV-positive patients. However, this effect is rapidly lost under effective antiretroviral therapy.
\end{abstract}




\section{Introduction}

The hallmark of HIV infection is gradual loss of $\mathrm{CD} 4^{+} \mathrm{T}$ cells, and apoptosis is now considered to contribute importantly to the declining numbers of $\mathrm{CD}^{+} \mathrm{T}$ cells in HIV-infected patients. Apoptosis is a highly regulated process which is characterised by specific physiological and morphological cell changes resulting in the formation of membrane-enclosed apoptotic bodies which are taken up by surrounding cells without an inflammatory reaction. Induction of apoptosis is mediated via different pathways. The extrinsic pathway is triggered by binding of ligands from the tumour-necrosis-factor (TNF) family to death receptors (Fas, DR4/5) which initiates activation of proteolytic enzymes, the cascade of caspases. Alternatively, apoptosis is induced in the intrinsic pathway via signals resulting from altered mitochondrial integrity. Both pathways converge at the level of caspase 3 activation, which induces irreversible steps of apoptosis such as cleavage of Poly-(ADP-ribose) polymerase (PARP).

Several mechanisms of apoptosis induction have been identified in HIV-infected individuals. Examples are killing by bystander cells due to the secretion of death ligands TRAIL and FasL, which are enhanced in HIV-infected patients. So called activation induced cell death (AICD) is another mechanism of apoptosis induction in HIV infection contributing to the loss of activated CD4 ${ }^{+} \mathrm{T}$ cells. Finally, HIV proteins themselves such as HIV Tat or Env proteins can directly interfere with host lymphocytes resulting in $\mathrm{CD}^{+} \mathrm{T}$ cell apoptosis [2-4].

Apoptosis is probably also a characteristic feature of hepatitis $\mathrm{C}$ virus $(\mathrm{HCV})$ infection. Apoptosis of hepatocytes and peripheral blood lymphocytes has been reported in HCV-infected patients [5]. However, the underlying mechanisms have remained unclear so far. Moreover, both direct pro- and anti-apoptotic effects have been reported for single HCV proteins [6]. Thus, the role of apoptosis is discussed controversially in the pathogenesis of chronic hepatitis $C$.

Due to similar routes of transmission 15-50\% of HIV-infected patients are HCV co-infected, resulting in an estimated ten million patients worldwide who suffer from combined HIV and HCV infection. Of note, certain populations with special risk factors, such as HIV-positive haemophilics and HIVpositive intravenous drug users, have 70-90\% prevalence of $\mathrm{HIV} / \mathrm{HCV}$ co-infection among their individuals [7]. HIV/HCV co-infection has been identified to lead to increased liver-related mortality and is considered to accelerate the progressive course of HIV-infection towards severe immunodeficiency and AIDS resulting in an increased overall mortality [8-13].

However, subsequent studies failed to confirm differences in survival between HIV-mono- and HIV/HCV-coinfected patients. For instance, analysis of the EuroSIDA cohort did not reveal any significant differences in decreased HIV loads and increased CD4-counts between HCV-positive and HCV-negative patients after the initiation of effective antiretroviral therapy [14, 15]. Highly active antiretroviral therapy (HAART) enables effective control over HIV replication and leads to recovery of $\mathrm{CD}^{+} \mathrm{T}$ cell counts. Thus, HAART can substantially increase the life expectancy of HIV-infected patients. Moreover, effective HAART results in reduced progression of HCV-associated liver disease and improved liver-related mortality in HIV/HCV-co-infected patients [16, 17]. Finally, immune reconstitution under HAART is also associated with marked reduction of $\mathrm{CD} 4^{+} \mathrm{T}$ cell apoptosis [14, $15]$.

However, concerning HIV/HCV-co-infected patients it is still unclear, to which extent $\mathrm{HCV}$ coinfection can modify rates of apoptosis in $\mathrm{CD} 4^{+} \mathrm{T}$ cells and if HAART can reduce apoptosis of $\mathrm{CD} 4^{+}$ $\mathrm{T}$ cells in these patients to the same degree as in HIV-mono-infected patients. Thus, applying two different assays for apoptosis detection in cross-sectional as well as longitudinal studies of HIV/HCVco-infected and HIV-mono-infected patients before and after the initiation of HAART, we directly compared $\mathrm{CD} 4^{+} \mathrm{T}$ cell apoptosis between HIV- and HIV/HCV-infected patients. 
Apoptosis in HIV/HCV co-infection

\section{Methods \\ Patients and controls}

A total of 94 patients and 12 healthy controls were enrolled in this study comprising 47 HIV-monoinfected, $37 \mathrm{HIV} / \mathrm{HCV}$-co-infected and $10 \mathrm{HCV}$-mono-infected patients. Of these, $25 \mathrm{HIV}$-monoinfected and $14 \mathrm{HIV} / \mathrm{HCV}$-co-infected patients had never been treated with antiretroviral drugs or had been without any antiretroviral treatment for at least one year prior to the study. 22 patients with HIV mono-infection and 23 patients with HIV/HCV co-infection had been receiving effective HAART for at least one year with HIV loads being consistently below the level of detection (less than 50 copies/ml). All HIV patients were infected with HIV-1. All patients with chronic HCV infection had not received any anti-HCV therapy prior to inclusion.

In addition to a cross-sectional analysis over all individuals, 8 HIV-mono-infected and $5 \mathrm{HIV} / \mathrm{HCV}$ co-infected patients could be studied sequentially during initiation of their first HAART (weeks 0, 4 and 12). Demographic and clinical details of all patients are summarized in table 1 and 2.

Informed consent was obtained from all patients; the study had been approved by the local ethics committee of the University of Bonn.

Isolation and short-term culture of peripheral blood mononuclear cells (PBMCs)

Peripheral blood mononuclear cells (PBMCs) were isolated by density centrifugation from peripheral blood samples with Ficoll Hypaque density gradients (Biochrom, Berlin, Germany). Isolated PBMCs were incubated for $20 \mathrm{~h}$ in 96 well plates at a concentration of $1 \times 10^{6} \mathrm{PBMC} / \mathrm{ml}$ in RPMI 1640 medium (PAA, Pasching, Austria) supplemented with 5\% (v/v) autologous serum and penicillin/streptomycin.

Detection of apoptotic $\mathrm{CD} 4^{+} \mathrm{T}$ cells

Rates of $\mathrm{CD} 4^{+} \mathrm{T}$ cells apoptosis were measured by detecting cells via cleaved poly (ADP-ribose) polymerase (PARP) and terminal deoxynucleotidyl transferase (TdT)-mediated dUTP-FITC nick end labelling (TUNEL), respectively. CD4 T cells in early stages of apoptosis were detected with specific antibody against cleaved PARP [1]. A commercially available TUNEL assay was used to detect DNA-fragmentation characteristic for cells in the late stages of apoptosis [18-21].

In brief, $1 \times 10^{6}$ PBMCs were stained with PerCP-conjugated anti-CD3 (BD Biosciences, Heidelberg, Germany) and allophycocyanin-conjugated (APC) anti-CD4 (BD Biosciences, Heidelberg, Germany) for $15 \mathrm{~min}$ at room temperature, washed with PBS and fixed then with paraformaldehyde (CellFIX, BD Biosciences, Heidelberg, Germany) for $20 \mathrm{~min}$ at $4^{\circ} \mathrm{C}$. Fixed cells were washed with PBSF [phosphate buffered saline supplemented with $0.01 \%$ (v/v) $\mathrm{NaN}_{3}, 2.5 \%$ (v/v) FCS (Biochrom, Berlin, Germany)] and then permeabilized with digitonin $\left(100 \mu \mathrm{g} / \mathrm{ml}\right.$ in PBSF) for $30 \mathrm{~min}$ at $4^{\circ} \mathrm{C}$. After additional washing steps, apoptotic cells were detected by incubation with a FITC-conjugated antibody which was specific for cleaved PARP (Abcam, Cambridge, UK) for $30 \mathrm{~min}$ at room temperature.

DNA fragmentation was measured with the APO-Direct-Kit (BD Biosciences, Heidelberg, Germany) according to the manufacturer's instructions. Briefly, $3 \times 10^{6}$ PBMC were stained with allophycocyanin-conjugated anti-CD4 antibody for $15 \mathrm{~min}$ at room temperature and then washed with PBS. Stained cells were fixed for $1 \mathrm{~h}$ with $1 \%(\mathrm{wt} / \mathrm{v})$ paraformaldehyde in PBS on ice, rinsed two times with cold PBS and finally resuspended in 70\% ethanol. Then, the cell suspension was stored for at least $24 \mathrm{~h}$ at $-20^{\circ} \mathrm{C}$. After washing two times with washing buffer fragmented $3^{\prime}-\mathrm{OH}$ DNA ends were labelled by incorporating FITC-labelled dUTP by incubating the cells with a terminal deoxynucleotidyl transferase reaction mixture at $37{ }^{\circ} \mathrm{C}$ for $1 \mathrm{~h}$. The reaction was stopped by washing two times with rinsing buffer and the cell suspension was incubated with RNAse/PI buffer for $30 \mathrm{~min}$ at room temperature prior to flowcytometric analysis.

Flowcytometric analysis was performed on FACSCalibur flowcytometer (BD Biosciences, Heidelberg, Germany) using CellQuest pro software (BD Biosciences, Heidelberg, Germany) and Flowjo (Tristar, Ashland, USA). 


\section{Determination of HIV and HCV load}

HCV genotypes were determined using the INNOLiPA, HCV II kit (Innogenetics, Heiden, Germany). HCV-RNA and HIV-RNA were measured by transcription- mediated amplification and branched DNA assays (TMA Versant, HCV 3.0 and HIV 3.0 Versant; Bayer Diagnostics, Leverkusen, Germany).

\section{$\underline{\text { Statistical analysis }}$}

Data are presented as median (interquartile range). Statistical comparisons between groups were done with the Mann-Whitney test using Prism 3.0 software (GraphPad, USA). Correlations between apoptosis, $\mathrm{CD}^{+} \mathrm{T}$ cell counts and viral loads were analyzed with Spearman rank correlation using Prism 3.0 software (GraphPad, USA). 
Apoptosis in HIV/HCV co-infection

\section{Results}

Both, the PARP and the TUNEL assay consistently yielded identical patterns of $\mathrm{CD} 4^{+} \mathrm{T}$ cell apoptosis in the different patient groups (figure 1), confirming that our assays were actually measuring spontaneous ex vivo apoptosis. Of note, we found marked differences in the levels of $\mathrm{CD} 4^{+} \mathrm{T}$ cell apoptosis between the different patient groups: While the percentage of apoptotic $\mathrm{CD} 4^{+} \mathrm{T}$ cells was identical in patients with chronic hepatitis $\mathrm{C}$ and healthy controls (PARP: $P=0.77$; TUNEL: $P=0.32$ ), HIV-positive patients displayed significantly increased rates of apoptotic $\mathrm{CD}^{+} \mathrm{T}$ cells (PARP: $P=0.0002$; TUNEL: $P<0.0001$ ) (figure 2). Importantly, the percentage of apoptotic $\mathrm{CD} 4^{+} \mathrm{T}$ cells was approximately twofold higher in HIV patients with HCV co-infection (PARP: $P=0.0157$; TUNEL: $P=0.0089)$ than in patients with HIV mono-infection. Rates of $\mathrm{CD}^{+} \mathrm{T}$ cell apoptosis were positively correlated to HIV viral loads in untreated patients with HCV coinfection as well as in untreated patients with HIV mono-infection (PARP: HIV $r_{\mathrm{s}}=0.66, P=0.0003$; $\mathrm{HIV} / \mathrm{HCV} r_{\mathrm{s}}=0.82, P=0.0002$; TUNEL: HIV $r_{\mathrm{s}}=0.66, P=0.0003$; HIV/HCV $\left.r_{\mathrm{s}}=0.79, P=0.0003\right)$. In contrast, neither in patients with $\mathrm{HCV}$ infection nor in patients with HIV/HCV co-infection $\mathrm{CD}^{+} \mathrm{T}$ cell apoptosis was correlated to HCV loads (data not shown). In addition, we could not identify any correlations between $\mathrm{CD} 4^{+} \mathrm{T}$ cell apoptosis and HCV genotypes, sex or age. However, the difference in $\mathrm{CD} 4^{+} \mathrm{T}$ cell apoptosis between HIV-mono-infected and HIV/HCV-co-infected patients was disproportionally greater in patients with high HIV loads indicating synergistic interactions between the two viruses.

\section{Effect of HAART on $\mathrm{CD}^{+} \mathrm{T}$ cell apoptosis}

When we analysed untreated patients and patients on effective HAART in a cross-sectional comparison, both HIV-mono-infected and HIV/HCV-co-infected patients on HAART revealed significantly lower rates of $\mathrm{CD}^{+} \mathrm{T}$ cell apoptosis than untreated patients (HIV: PARP: $P=0.032$, TUNEL: $P=0.039$; HIV/HCV: PARP: $P=0.0005$, TUNEL: $P<0.0001$ ) (figure 3). Furthermore, $\mathrm{CD} 4^{+}$ $\mathrm{T}$ cells apoptosis of HIV-mono-infected patients was not different from apoptosis in HIV/HCV-coinfected subjects under effective HAART. Nevertheless, rates of $\mathrm{CD}^{+} \mathrm{T}$ cell apoptosis in treated HIV patients remained still above the level of healthy controls (HIV: PARP: $P<0.0001$, TUNEL: $P=0.039$; HIV/HCV: PARP: $P<0.0001$, TUNEL: $P<0.0001)$.

Stratification of all HAART-treated patients into PI- and non PI-based regimens revealed significant differences: Patients treated with protease inhibitors displayed higher rates of residual $\mathrm{CD} 4^{+} \mathrm{T}$ cell apoptosis than patients treated exclusively with NRTI or NNRTI/NRT combinations (PARP: $P=0.0033$; TUNEL: $P=0.0242$ ) (figure 3 ). This difference between PI- and non PI-based HAART was independent of $\mathrm{HCV}$ co-infection.

\section{Changes of $\mathrm{CD}^{+} \mathrm{T}$ cell apoptosis during immune reconstitution}

Longitudinal analysis of $\mathrm{CD} 4^{+} \mathrm{T}$ cell apoptosis during immune reconstitution revealed decreasing levels of $\mathrm{CD}^{+} \mathrm{T}$ cell apoptosis in both, HIV-mono- and HIV/HCV-co-infected patients. Mean levels of $\mathrm{CD}^{+} \mathrm{T}$ cell apoptosis patients had been higher in HIV/HCV-co-infected patients than in HIVmono-infected patients before HAART (figure 4 C/D) but decreased more vigorously than in HIVmono-infected patients during the first four weeks of treatment (HIV: PARP: $-1.22 \%$, TUNEL: 1.43\%; HIV/HCV: PARP. $-4.96 \%$, TUNEL: $-4.06 \%$ ), while increases in $\mathrm{CD}^{+} \mathrm{T}$ cell counts (HIV: +124 cells $/ \mathrm{ml}$; HIV/HCV: +108 cells $/ \mathrm{ml}$ ) and inhibition of HIV replication (HIV: $-2.47 \mathrm{log}$; HIV/HCV: $-2.53 \log$ ) did not reveal significant differences between the two patient groups.

Measurements twelve weeks after initiation of HAART confirmed that levels of $\mathrm{CD}^{+} \mathrm{T}$ cell apoptosis were identical in HIV/HCV-co-infected patients and HIV-mono-infected patients (figure 4 C/D). In addition, increases in CD4 $4^{+} \mathrm{T}$ cell count (HIV: $+135 \mathrm{cells} / \mathrm{ml}$; HIV/HCV: +133 cells $/ \mathrm{ml}$ ) as well as drop in HIV loads (HIV: -3.49 log; HIV/HCV: - $3.46 \log$ ) were equivalent in HIV- and $\mathrm{HIV} / \mathrm{HCV}$-co-infected patients 12 weeks after the start of HAART (figure $4 \mathrm{~A} / \mathrm{B}$ ). 
Apoptosis in HIV/HCV co-infection

\section{Discussion}

Apoptosis of $\mathrm{CD}^{+} \mathrm{T}$ cells has been repeatedly incriminated as a major process underlying the loss of $\mathrm{CD}^{+}{ }^{+} \mathrm{T}$ cells in HIV-positive patients. However, the role of $\mathrm{HCV}$ co-infection for progression of HIV disease and particularly apoptosis of $\mathrm{CD} 4^{+} \mathrm{T}$ cells has remained controversial thus far.

In this study we investigated DNA fragmentation and cleavage of PARP in $\mathrm{CD}^{+} \mathrm{T}$ cells which together reflect irreversible changes associated with induction of apoptosis. Our data confirm high rates of apoptosis in $\mathrm{CD} 4^{+} \mathrm{T}$ cells of HIV-positive patients. Notably, apoptosis of $\mathrm{CD} 4^{+} \mathrm{T}$ cells in HIV/HCV-co-infected patients markedly exceeded the levels observed in patients with HIV monoinfection, whereas HCV infection alone resulted in rates of apoptosis, which were identical to healthy controls. Taken together, these findings indicate that although HCV infection alone did not induce apoptosis in $\mathrm{CD}^{+}{ }^{+} \mathrm{T}$ cells, it sensitizes $\mathrm{CD} 4^{+} \mathrm{T}$ cells towards the apoptotic effects of HIV infection.

These results corroborate a previous observation reporting that HCV/HIV-co-infected patients had particularly high rates of annexin $\mathrm{V}$ binding in $\mathrm{CD}^{+} \mathrm{T}$ cells, a possible marker of early apoptosis [22]. However, unlike this previous study our data were based on markers of irreversible apoptosis and also differentiated rates of apoptosis between HIV-mono- and HIV/HCV-doubly-infected patients as well as treated and untreated patients, respectively. Our data seem also to correspond to findings in HepG2 cells, where collaborative induction of apoptosis has been reported for the interaction of $\mathrm{HCV}$ and HIV envelope proteins [23]. However, in HepG2 cells either viral protein alone did not induce apoptosis, whereas in our study apoptosis of $\mathrm{CD}^{+} \mathrm{T}$ cells was already increased in HIV monoinfection. Thus, further mechanisms must be involved, which sensitized $\mathrm{CD}^{+} \mathrm{T}$ cells towards apoptosis induction in patients with untreated HIV/HCV co-infection.

Although it was shown that HIV-driven immune activation is correlated with apoptosis of $\mathrm{CD}^{+} \mathrm{T}$ cells in HIV mono-infection, Nunez et al. did not find any association between $\mathrm{T}$ cell activation and $\mathrm{CD}^{+}{ }^{+} \mathrm{T}$ cell apoptosis in HIV/HCV-coinfected patients [22]. This does not rule out increased production of pro-inflammatory cytokines or altered expression of death receptors and their corresponding ligands. Indeed, up-regulated expression of death receptors FAS as well as TRAIL receptors I and II has independently described in HCV and HIV mono-infected patients and seems to correspond to increased serum levels of death receptor ligands FasL, TRAIL and TNF alpha [24-30]. In particular, soluble TRAIL is increased in HIV infection closely related to the level of HIV replication. Moreover, HIV-Tat-stimulated monocytes have been demonstrated to kill $\mathrm{CD}^{+}{ }^{+} \mathrm{T}$ cells via TRAIL-dependent apoptosis [31, 32]. In this context it is noteworthy that HCV core protein has been shown to sensitize Huh7 cells towards apoptosis mediated by TRAIL [33]. This finding has been attributed to enhanced apoptosis signalling via sequential induction of caspase 8, Bid cleavage, activation of the mitochondrial pathway and activation of effector caspase 3 as well as direct activation of caspase 9. Since cleavage of PARP and DNA fragmentation are apoptotic events downstream of caspase 3 activation, we could not differentiate which pathway of apoptosis activation was enhanced in $\mathrm{CD}^{+} \mathrm{T}$ cells from $\mathrm{HIV} / \mathrm{HCV}$-co-infected patients.

Although the exact mechanisms underlying apoptosis sensitisation remain unclear thus far, our results suggest a pivotal role for HIV replication. First, rates of apoptosis in HIV/HCV-co-infected patients were increased the more over HIV-mono-infected patients the higher the level of HIV replication. Next, this effect was fully reversed when HIV replication was suppressed by effective HAART, as shown by our cross-sectional comparison and the individual serial longitudinal studies in single patients. Of note, the decline of apoptosis rates was more pronounced in HIV/HCV-co-infected patients at week 4 than in HIV-mono-infected patients, although HIV replication had been inhibited to the same degree in both groups. Although rates of apoptosis further declined in the subsequent weeks on HAART, residual apoptosis in $\mathrm{CD} 4^{+} \mathrm{T}$ cells still remained above the level of healthy controls and HCV-mono-infected patients but did no longer reveal any significant differences between HIV-and HIV/HCV-co-infected patients. This may reflect effects resulting from ongoing HIV replication below the level of detection on one hand. On the other hand unexpected adverse effects due to the anti-retroviral agents must also be considered. In this context it was an intriguing finding, that residual $\mathrm{CD}^{+} \mathrm{T}$ cell apoptosis was significantly higher in patients on PI-based HAART regimens than on non PI-regimens. Although PIs block cellular apoptosis at the level of mitochondrial pore proteins, paradoxical pro-apoptotic effects have been reported in vitro at high concentrations both in 
hematological cell lines and solid tumors $[34,35]$. Increased in vitro apoptosis from PIs was either associated with inhibited transcriptional activation of $\mathrm{NF}-\kappa \mathrm{B}$ together with inhibited expression of its targets BcL-X $\mathrm{X}_{\mathrm{L}}$, survivin, c-Myc and cyclin D2 [34] or an increase in the cellular concentration of the antiproliferative and proapoptotic proteasome substrate cdK inhibitor p21 [35]. This reasoning is consistent with an earlier report that HIV PI have an impact on proteasome activity [36]. Furthermore, in vitro inhibition of cells with ritonavir, saquinavir or nelfinavir was associated with decreased expression of the anti-apoptotic protein McL-1 as well as blocked IL-6 mediated phosphorylation of ERK 1/2 and STAT3 [37].

Unfortunately, however, we do not have data to clarify if resolution of hepatitis $\mathrm{C}$ by anti-HCV treatment can reduce $\mathrm{CD}^{+} \mathrm{T}$ cell apoptosis to the same degree as antiretroviral therapy, since all our interferon-treated patients had been on antiretroviral therapy prior to anti-HCV treatment. Thus, the relationship between anti-HCV treatment and $\mathrm{CD}^{+} \mathrm{T}$ cell apoptosis still needs to be clarified in future projects.

Whatever the molecular and cellular mechanisms, our data clearly demonstrate that HIV/HCV-coinfected patients without effective HAART suffer increased apoptosis of CD4 ${ }^{+} \mathrm{T}$ cells and thus, are prone to progress more rapidly to severe immunodeficiency. Moreover, our data may help to understand why clinical data on HIV progression in patients with hepatitis $\mathrm{C}$ co-infection are controversial. For, in our comprehensive study a negative impact on disease progression was only noted in untreated patients, and rates of $\mathrm{CD}^{+} \mathrm{T}$ cell apoptosis became identical between HIV and HIV/HCV-co-infected patients shortly after initiation of HAART. Although differences in outcome between HIV and HIV/HCV-co-infected patients have been reported [8, 38, 39], our findings would support several recent longitudinal observations of HIV/HCV-co-infected patients which suggest there are no relevant differences in immune recovery between HIV and HIV/HCV-co-infected patients on long-term HAART [14, 40, 41]. In line with these results, early initiation of antiretroviral therapy in HIV/HCV-co-infected patients is not only a good way to reduce liver-related mortality but may also be an effective measure to prevent excessive loss of $\mathrm{CD}^{+}{ }^{+} \mathrm{T}$ cells in $\mathrm{HIV} / \mathrm{HCV}$ co-infection [42]. 


\section{Acknowledgements}

All authors made substantial contribution to this research project. None of the authors has any conflict of interest related to this study.

We also are grateful for the contributions made by J.-C. Wasmuth, C. Schwarze-Zander and Jetske Emmelkamp.

\section{Funding}

This work was supported by a grant from the German Federal Ministry of Education and Research (BMBF) within the network for resistance in hepatitis C, grant number [01KI0792].

J. Nattermann was supported by a grant from the H.W. \& J. Hector foundation, grant number [M42]. 


\section{References}

1 Lazebnik, Y. A., Kaufmann, S. H., Desnoyers, S., Poirier, G. G. and Earnshaw, W. C. (1994) Cleavage of poly(ADP-ribose) polymerase by a proteinase with properties like ICE. Nature 371, 346-347.

2 Alimonti, J. B., Ball, T. B. and Fowke, K. R. (2003) Mechanisms of CD4+ T lymphocyte cell death in human immunodeficiency virus infection and AIDS. J Gen Virol 84, 1649-1661.

3 Miura, Y. and Koyanagi, Y. (2005) Death ligand-mediated apoptosis in HIV infection. Rev Med Virol 15, 169-178.

4 Varbanov, M., Espert, L. and Biard-Piechaczyk, M. (2006) Mechanisms of CD4 T-cell depletion triggered by HIV-1 viral proteins. AIDS Rev 8, 221-236.

5 Taya, N., Torimoto, Y., Shindo, M., Hirai, K., Hasebe, C. and Kohgo, Y. (2000) Fas-mediated apoptosis of peripheral blood mononuclear cells in patients with hepatitis C. Br J Haematol 110, 89-97.

6 Fischer, R., Baumert, T. and Blum, H. E. (2007) Hepatitis C virus infection and apoptosis. World J Gastroenterol 13, 4865-4872.

7 Rockstroh, J. K. and Spengler, U. (2004) HIV and hepatitis C virus co-infection. Lancet Infect Dis. 4, 437-444.

8 Anderson, K. B., Guest, J. L. and Rimland, D. (2004) Hepatitis C virus coinfection increases mortality in HIV-infected patients in the highly active antiretroviral therapy era: data from the HIV Atlanta VA Cohort Study. Clin Infect Dis. 39, 1507-1513. Epub 2004 Oct 1525.

9 Greub, G., Ledergerber, B., Battegay, M., Grob, P., Perrin, L., Furrer, H., Burgisser, P., Erb, P., Boggian, K., Piffaretti, J. C., Hirschel, B., Janin, P., Francioli, P., Flepp, M. and Telenti, A. (2000) Clinical progression, survival, and immune recovery during antiretroviral therapy in patients with HIV1 and hepatitis C virus coinfection: the Swiss HIV Cohort Study. Lancet. 356, 1800-1805.

10 Giordano, T. P., Kramer, J. R., Souchek, J., Richardson, P. and El-Serag, H. B. (2004) Cirrhosis and hepatocellular carcinoma in HIV-infected veterans with and without the hepatitis C virus: a cohort study, 1992-2001. Arch Intern Med. 164, 2349-2354.

11 Pineda, J. A., Romero-Gomez, M., Diaz-Garcia, F., Giron-Gonzalez, J. A., Montero, J. L., TorreCisneros, J., Andrade, R. J., Gonzalez-Serrano, M., Aguilar, J., Aguilar-Guisado, M., Navarro, J. M., Salmeron, J., Caballero-Granado, F. J. and Garcia-Garcia, J. A. (2005) HIV coinfection shortens the survival of patients with hepatitis C virus-related decompensated cirrhosis. Hepatology. 41, 779-789.

12 Kramer, J. R., Giordano, T. P., Souchek, J. and El-Serag, H. B. (2005) Hepatitis C coinfection increases the risk of fulminant hepatic failure in patients with HIV in the HAART era. J Hepatol. 42, 309-314.

13 El-Serag, H. B., Giordano, T. P., Kramer, J., Richardson, P. and Souchek, J. (2005) Survival in hepatitis C and HIV co-infection: a cohort study of hospitalized veterans. Clin Gastroenterol Hepatol. 3, 175-183.

14 Rockstroh, J. K., Mocroft, A., Soriano, V., Tural, C., Losso, M. H., Horban, A., Kirk, O., Phillips, A., Ledergerber, B. and Lundgren, J. (2005) Influence of hepatitis C virus infection on HIV-1 disease progression and response to highly active antiretroviral therapy. J Infect Dis 192, 992-1002. Epub 2005 Aug 1011.

15 Roger, P. M., Breittmayer, J. P., Arlotto, C., Pugliese, P., Pradier, C., Bernard-Pomier, G., Dellamonica, P. and Bernard, A. (1999) Highly active anti-retroviral therapy (HAART) is associated with a lower level of CD4+ T cell apoptosis in HIV-infected patients. Clin Exp Immunol. 118, 412 416.

16 Qurishi, N., Kreuzberg, C., Luchters, G., Effenberger, W., Kupfer, B., Sauerbruch, T., Rockstroh, J. K. and Spengler, U. (2003) Effect of antiretroviral therapy on liver-related mortality in patients with HIV and hepatitis $\mathrm{C}$ yirus coinfection. Lancet. 362, 1708-1713.

17 Brau, N., Salvatore, M., Rios-Bedoya, C. F., Fernandez-Carbia, A., Paronetto, F., Rodriguez-Orengo, J. F. and Rodriguez-Torres, M. (2006) Slower fibrosis progression in HIV/HCV-coinfected patients with successful HIV suppression using antiretroviral therapy. J Hepatol 44, 47-55. Epub 2005 Jul 2027.

18 Enari, M., Sakahira, H., Yokoyama, H., Okawa, K., Iwamatsu, A. and Nagata, S. (1998) A caspaseactivated DNase that degrades DNA during apoptosis, and its inhibitor ICAD. Nature 391, 43-50.

19 Sakahira, H., Enari, M. and Nagata, S. (1998) Cleavage of CAD inhibitor in CAD activation and DNA degradation during apoptosis. Nature 391, 96-99.

20 Walker, P. R., Kokileva, L., LeBlanc, J. and Sikorska, M. (1993) Detection of the initial stages of DNA fragmentation in apoptosis. Biotechniques. 15, 1032-1040.

21 Darzynkiewicz, Z., Juan, G., Li, X., Gorczyca, W., Murakami, T. and Traganos, F. (1997) Cytometry in cell necrobiology: analysis of apoptosis and accidental cell death (necrosis). Cytometry. 27, 1-20. 
Nunez, M., Soriano, V., Lopez, M., Ballesteros, C., Cascajero, A., Gonzalez-Lahoz, J. and Benito, J. M. (2006) Coinfection with hepatitis C virus increases lymphocyte apoptosis in HIV-infected patients. Clin Infect Dis 43, 1209-1212. Epub 2006 Sep 1227.

23 Munshi, N., Balasubramanian, A., Koziel, M., Ganju, R. K. and Groopman, J. E. (2003) Hepatitis C and human immunodeficiency virus envelope proteins cooperatively induce hepatocytic apoptosis via an innocent bystander mechanism. J Infect Dis. 188, 1192-1204. Epub 2003 Sep 1130.

24 Iio, S., Hayashi, N., Mita, E., Ueda, K., Mochizuki, K., Hiramatsu, N., Kanto, T., Sasaki, Y., Kasahara, A. and Hori, M. (1998) Serum levels of soluble Fas antigen in chronic hepatitis C patients. J Hepatol. 29, 517-523.

25 Zylberberg, H., Rimaniol, A. C., Pol, S., Masson, A., De Groote, D., Berthelot, P., Bach, J. F., Brechot, C. and Zavala, F. (1999) Soluble tumor necrosis factor receptors in chronic hepatitis C: a correlation with histological fibrosis and activity. J Hepatol. 30, 185-191.

26 Zhang, M., Li, X., Pang, X., Ding, L., Wood, O., Clouse, K., Hewlett, I. and Dayton, A. I. (2001) Identification of a potential HIV-induced source of bystander-mediated apoptosis in $\mathrm{T}$ cells: upregulation of trail in primary human macrophages by HIV-1 tat. J Biomed Sci. 8, 290-296.

27 Bahr, G. M., Capron, A., Dewulf, J., Nagata, S., Tanaka, M., Bourez, J. M. and Mouton, Y. (1997) Elevated serum level of Fas ligand correlates with the asymptomatic stage of human immunodeficiency virus infection. Blood. 90, 896-898.

28 Fadeel, B., Samuelsson, A., Hachiya, T., Brostrom, C. and Chiodi, F. (1996) Elevated serum levels of soluble Fas/APO-1 in human immunodeficiency virus-infected individuals. Blood. 88, 4727-4730.

29 Badley, A. D., Dockrell, D. H., Algeciras, A., Ziesmer, S., Landay, A., Lederman, M. M., Connick, E., Kessler, H., Kuritzkes, D., Lynch, D. H., Roche, P., Yagita, H. and Paya, C. V. (1998) In vivo analysis of Fas/FasL interactions in HIV-infected patients. J Clin Invest. 102, 79-87.

30 Katsikis, P. D., Wunderlich, E. S., Smith, C. A. and Herzenberg, L. A. (1995) Fas antigen stimulation induces marked apoptosis of $\mathrm{T}$ lymphocytes in human immunodeficiency virus-infected individuals. J Exp Med. 181, 2029-2036.

31 Herbeuval, J. P., Boasso, A., Grivel, J. C., Hardy, A. W., Anderson, S. A., Dolan, M. J., Chougnet, C., Lifson, J. D. and Shearer, G. M. (2005) TNF-related apoptosis-inducing ligand (TRAIL) in HIV-1infected patients and its in vitro production by antigen-presenting cells. Blood. 105, 2458-2464. Epub 2004 Dec 2457.

32 Yang, Y., Tikhonov, I., Ruckwardt, T. J., Djavani, M., Zapata, J. C., Pauza, C. D. and Salvato, M. S. (2003) Monocytes treated with human immunodeficiency virus Tat kill uninfected CD4(+) cells by a tumor necrosis factor-related apoptosis-induced ligand-mediated mechanism. J Virol. 77, 6700-6708.

33 Chou, A. H., Tsai, H. F., Wu, Y. Y., Hu, C. Y., Hwang, L. H., Hsu, P. I. and Hsu, P. N. (2005) Hepatitis $\mathrm{C}$ virus core protein modulates TRAIL-mediated apoptosis by enhancing Bid cleavage and activation of mitochondria apoptosis signaling pathway. J Immunol. 174, 2160-2166.

34 Dewan, M. Z., Uchihara, J. N., Terashima, K., Honda, M., Sata, T., Ito, M., Fujii, N., Uozumi, K., Tsukasaki, K., Tomonaga, M., Kubuki, Y., Okayama, A., Toi, M., Mori, N. and Yamamoto, N. (2006) Efficient intervention of growth and infiltration of primary adult T-cell leukemia cells by an HIV protease inhibitor, ritonavir. Blood. 107, 716-724. Epub 2005 Sep 2020.

35 Gaedicke, S., Firat-Geier, E., Constantiniu, O., Lucchiari-Hartz, M., Freudenberg, M., Galanos, C. and Niedermann, G. (2002) Antitumor effect of the human immunodeficiency virus protease inhibitor ritonavir: induction of tumor-cell apoptosis associated with perturbation of proteasomal proteolysis. Cancer Res. 62, 6901-6908.

36 Andre, P., Groettrup, M., Klenerman, P., de Giuli, R., Booth, B. L., Jr., Cerundolo, V., Bonneville, M., Jotereau, F., Zinkernagel, R. M. and Lotteau, V. (1998) An inhibitor of HIV-1 protease modulates proteasome activity, antigen presentation, and T cell responses. Proc Natl Acad Sci U S A. 95, 1312013124.

37 Ikezoe, T., Saito, T., Bandobashi, K., Yang, Y., Koeffler, H. P. and Taguchi, H. (2004) HIV-1 protease inhibitor induces growth arrest and apoptosis of human multiple myeloma cells via inactivation of signal transducer and activator of transcription 3 and extracellular signal-regulated kinase 1/2. Mol Cancer Ther. 3, 473-479.

38 De Luca, A., Bugarini, R., Lepri, A.C., Puoti, M., Girardi, E., Antinori, A., Poggio, A., Pagano, G., Tositti, G., Cadeo, G., Macor, A., Toti, M., D'Arminio Monforte, A.; Italian Cohort Naive Antiretrovirals Study Group. (2002) Coinfection with hepatitis viruses and outcome of initial antiretroviral regimens in previously naive HIV-infected subjects. Arch Intern Med 162, 2125-2132.

39 Braitstein, P., Zala, C., Yip, B., Brinkhof, M.W., Moore, D., Hogg, R.S., Montaner, J.S. (2006) Immunologic response to antiretroviral therapy in hepatitis $\mathrm{C}$ virus-coinfected adults in a populationbased HIV/AIDS treatment program. J Infect Dis 193, 259-268. Epub 2005 Dec 2007. 
40 Yacisin, K., Maida, I., Rios, M. J., Soriano, V. and Nunez, M. (2008) Hepatitis C virus coinfection does not affect CD4 restoration in HIV-infected patients after initiation of antiretroviral therapy. AIDS Res Hum Retroviruses 24, 935-940.

41 Sulkowski, M. S., Moore, R. D., Mehta, S. H., Chaisson, R. E. and Thomas, D. L. (2002) Hepatitis C and progression of HIV disease. Jama. 288, 199-206.

42 Shafran, S. D. (2007) Early initiation of antiretroviral therapy: the current best way to reduce liverrelated deaths in HIV/hepatitis C virus-coinfected patients. J Acquir Immune Defic Syndr. 44, 551-556, 
Apoptosis in HIV/HCV co-infection

\section{Tables}

\begin{tabular}{|c|c|c|c|c|c|c|}
\hline \multirow[t]{2}{*}{ Characteristic } & \multirow{2}{*}{$\begin{array}{l}\text { Healthy } \\
\text { controls }\end{array}$} & \multirow[t]{2}{*}{$\mathrm{HCV}$} & \multicolumn{2}{|c|}{ HIV } & \multicolumn{2}{|c|}{$\mathrm{HIV} / \mathrm{HCV}$} \\
\hline & & & no HAART & HAART & no HAART & HAART \\
\hline Number & 12 & 10 & 25 & 22 & 14 & \\
\hline Female sex ${ }^{\text {a) }}$ & $5(42.0 \%)$ & $4(40.0 \%)$ & $5(20.0 \%)$ & $6(27.3 \%)$ & $2(14.3 \%)$ & $7(30.4 \%)$ \\
\hline Age (years) ${ }^{\text {b) }}$ & $36.7(26-51)$ & $40.5(19-78)$ & $42.5(28-67)$ & $44.8(27-69)$ & $42.8(32-60)$ & $42.5(30-53)$ \\
\hline \multicolumn{7}{|l|}{ Risk factors } \\
\hline I.V. drugs ${ }^{\text {a) }}$ & - & $7(70.0 \%)$ & $0(0.0 \%)$ & $4(18.2 \%)$ & $7(50.0 \%)$ & $9(39.1 \%)$ \\
\hline Blood Transfusion ${ }^{\text {a) }}$ & - & $1(10.0 \%)$ & $0(0.0 \%)$ & $1(4.5 \%)$ & $0(0.0 \%)$ & $0(0.0 \%)$ \\
\hline Heterosexual ${ }^{\text {a) }}$ & - & $0(0.0 \%)$ & $5(20.0 \%)$ & $3(13.6 \%)$ & $0(0.0 \%)$ & $2(8.7 \%)$ \\
\hline Haemophilia a) & - & $0(0.0 \%)$ & $1(4.0 \%)$ & $4(18.2 \%)$ & $2(14.3 \%)$ & $7(30.4 \%)$ \\
\hline $\operatorname{MSM}^{a), c)}$ & - & $0(0.0 \%)$ & $15(60.0 \%)$ & $6(27.3 \%)$ & $3(21.4 \%)$ & $2(8.7 \%)$ \\
\hline Endemic $^{\text {a) }}$ & - & $0(0.0 \%)$ & $3(12.0 \%)$ & $(13.6 \%)$ & $2(14.3 \%)$ & $0(0.0 \%)$ \\
\hline Unknown $^{\text {a) }}$ & - & $2(20.0 \%)$ & $2(8.0 \%)$ & $1(4.5 \%)$ & $0(0.0 \%)$ & $3(13.1 \%)$ \\
\hline \multicolumn{7}{|l|}{ HIV status } \\
\hline $\begin{array}{l}\text { HIV load } \\
\left(\mathrm{x} 10^{3} \text { copies } / \mathrm{ml}\right)\end{array}$ & - & - & $39.9(0.05-37$ & $<0.05$ & $46.1(0.45-548)$ & $<0.05$ \\
\hline $\mathrm{CD} 4^{+}$cells $/ \mu \mathrm{l}^{\mathrm{d})}$ & n.a. ${ }^{e}$ & n.a. ${ }^{\text {e) }}$ & $371(11-1235)$ & $459(134-1000)$ & $350(40-1000)$ & $430(38-1088)$ \\
\hline $\mathrm{CD} 8^{+}$cells $/ \mu 1^{\mathrm{d})}$ & n.a. ${ }^{e}$ & n.a.e ${ }^{\text {e }}$ & $780(324-1727)$ & $815(160-1491)$ & 1034 (589-2229) & $933(410-1937)$ \\
\hline \multicolumn{7}{|l|}{ HCV status } \\
\hline $\begin{array}{l}\text { HCV load } \\
\left(x 10^{6} \text { copies/ml) }\right.\end{array}$ & - & $5.8(0.02-25)$ & & - & $7.7(0.09-25.7)$ & $15.5(0.01-74)$ \\
\hline Genotype 1 & - & $10(100 \%)$ & $->$ & - & $8(57.1 \%)$ & $13(56.5 \%)$ \\
\hline Non genotype 1 & - & $0(0.0 \%)$ & - & - & $6(42.9 \%)$ & $10(43.5 \%)$ \\
\hline
\end{tabular}


Apoptosis in HIV/HCV co-infection

Table 2. Characteristics of HAART-treated patients

\begin{tabular}{|c|c|c|c|}
\hline Characteristic & $\begin{array}{c}\text { HAART } \\
\text { all }\end{array}$ & $\begin{array}{l}\text { HAART } \\
\text { PI-based }\end{array}$ & $\begin{array}{c}\text { HAART } \\
\text { Non PI-based }\end{array}$ \\
\hline Number & 45 & 31 & 14 \\
\hline Female sex ${ }^{a)}$ & $13(28.9 \%)$ & $7(22.6 \%)$ & $6(42.8 \%)$ \\
\hline Age (years) ${ }^{b)}$ & $42.3(27-69)$ & $41.7(27-69)$ & $43.7(30-55)$ \\
\hline HCV-co-infected & $23(51.1 \%)$ & $17(54.8 \%)$ & $6(42.9 \%)$ \\
\hline \multicolumn{4}{|c|}{ Protease inhibitors (PI) } \\
\hline Atazanavir & 9 & $9(29.0 \%)$ & - \\
\hline Lopinar/Ritonavir & 19 & $19(61.3 \%)$ & - \\
\hline Saquinavir & 2 & $2(6.5 \%)$ & - \\
\hline Ritonavir + PI & 5 & $5(16.1 \%)$ & - \\
\hline Frosamprenavir & 1 & $1(3.2 \%)$ & - \\
\hline \multicolumn{4}{|l|}{ NNRTI } \\
\hline Efavirenz & 9 & - & $9(64.3 \%)$ \\
\hline \multicolumn{4}{|l|}{ NRTI } \\
\hline Tenofovir & $32(71.1 \%)$ & $24(77.4 \%)$ & $8(57.1 \%)$ \\
\hline Emtricitabin & $24(53.3 \%)$ & $17(54.8 \%)$ & $7(50.0 \%)$ \\
\hline Lamivudin & $24(53.3 \%)$ & $16(51.6 \%)$ & $8(57.1 \%)$ \\
\hline Abacavir & $12(26.7 \%)$ & $7(22.6 \%)$ & $5(35.7 \%)$ \\
\hline Zidovudin & $5(11.1 \%)$ & $0(0.0 \%)$ & $5(35.7 \%)$ \\
\hline
\end{tabular}




\section{Titles and legends to figures}

Figure 1. Flowcytometric analysis of $\mathrm{CD4}^{+} \mathbf{T}$ cells. Representative dot plots from patients from each group with apoptosis determined by PARP (columns 2, 3) and TUNEL assay (columns 4, 5). The dot plot of the isotype control is representative for all controls from each patient (column 1). Lymphocytes were gated by side and forward scatter. $\mathrm{CD} 4^{+} \mathrm{T}$ cells were defined as $\mathrm{CD} 3{ }^{+} / \mathrm{CD} 4^{+}-$ positive lymphocytes. Apoptotic cells are PARP-positive as determined in the lower right quadrant. Late apoptotic cells show high levels of DNA fragmentation (TUNEL) as determined in the lower right quadrant.

Figure 2. (A/B) Percentage of $\mathrm{CD}^{+} \mathrm{T}$ cells with apoptosis in different patient groups. Figure $2 \mathrm{~A}$ shows the results obtained with the PARP assay. Figure $2 \mathrm{~B}$ illustrates rates of $\mathrm{CD} 4^{+} \mathrm{T}$ cell apoptosis determined by DNA fragmentation (TUNEL assay). Box plots (median, interquartile range) display levels of apoptosis in healthy controls $(n=12), \mathrm{HCV}$-mono-infected patients $(n=10)$ and HIV-monoinfected $(n=25)$ as well as HIV/HCV-co-infected subjects $(n=14)$. Statistical comparisons between groups were done with the Mann-Whitney test using Prism 3.0 software (GraphPad, USA). (C/D) Associations between HIV load and $\mathrm{CD}^{+} \mathrm{T}$ cell apoptosis. CD4 ${ }^{+} \mathrm{T}$ cell apoptosis of HIVmonoinfected and HIV/HCV-co-infected patients is plotted versus HIV loads. (C) $\mathrm{CD}^{+} \mathrm{T}$ cell apoptosis determined by PARP assay is correlated to HIV loads both in HIV-mono-infected and HIV/HCV-co-infected patients (HIV: $r_{\mathrm{s}}=0.66, P=0.0003 ; \mathrm{HIV} / \mathrm{HCV}: r_{\mathrm{s}}=0.82, P=0.0002$ ). (D) Levels of $\mathrm{CD}^{+} \mathrm{T}$ cell apoptosis determined by TUNEL assay is correlated to HIV loads (HIV: $r_{\mathrm{s}}=0.66$, $\left.P=0.0003 ; \mathrm{HIV} / \mathrm{HCV}: r_{\mathrm{s}}=0.79, P=0.0003\right)$. Correlations between apoptosis and viral loads were analyzed with Spearman rank correlation using Prism 3.0 software (GraphPad, USA).

Figure 3. Impact of effective HAART on $\mathrm{CD}^{+} \mathbf{T}$ cell apoptosis. Percentage of $\mathrm{CD} 4^{+} \mathrm{T}$ cells with apoptosis in HIV-mono-infected and HIV/HCV-co-infected patients with $(n=22, n=23)$ and without effective HAART respectively $(n=25, n=14)$. Columns A and C refer to the PARP assay, columns B and $\mathrm{D}$ to the TUNEL. In figure $\mathrm{C}$ and $\mathrm{D}$ patients were stratified with respect to the type of HAART, irrespective from HCV co-infection. Statistical comparisons between groups were done with the Mann-Whitney test using Prism 3.0 software (GraphPad, USA).

Figure 4. Changes of $\mathrm{CD}^{+} \mathbf{T}$ cell apoptosis during Immune reconstitution. (A) $\mathrm{CD}^{+} \mathrm{T}$ cell counts at baseline, 4 and 12 weeks after HAART initiation of HIV-mono $(n=8)$ and HIV/HCV-coinfected ( $\mathrm{n}=5)$ patients. (B) HIV loads at baseline, 4 and 12 weeks after HAART initiation of HIVmono and HIV/HCV-co-infected patients. Percentage of $\mathrm{CD}^{+} \mathrm{T}$ cell apoptosis at baseline, 4 and 12 weeks after HAART initiation in HIV-mono and HIV/HCV-co-infected patients determined by PARP assay (C) and TUNEL assay (D). 
Fig. 1

A)

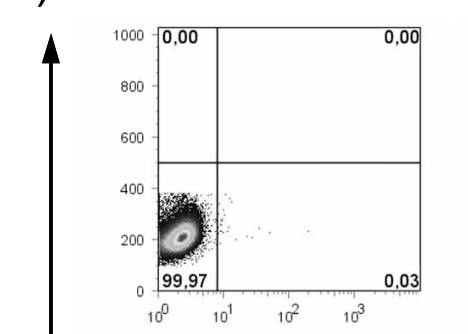

Isotype Control

no
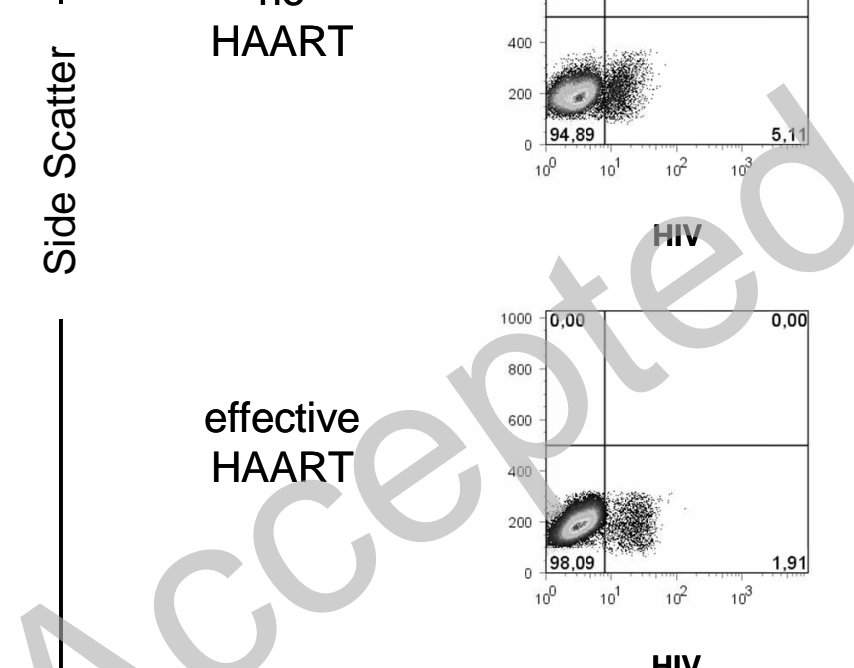

HIV

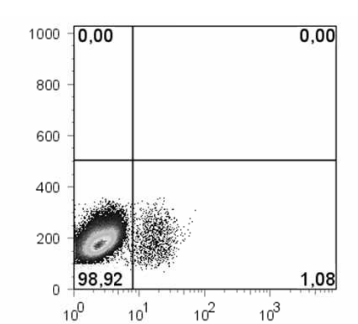

Healthy control

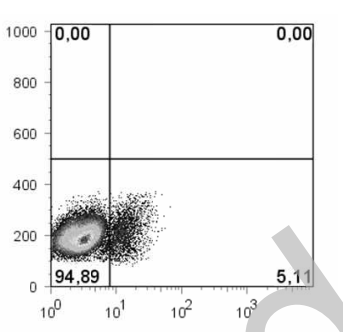

HIV

cleaved PARP

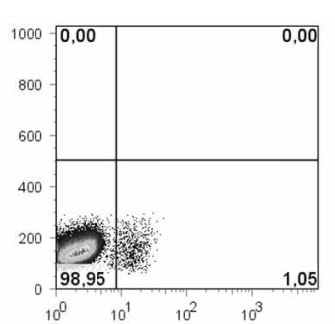

HCV

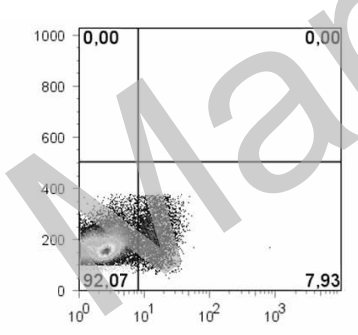

HIV/HCV

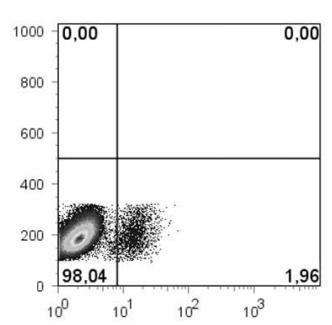

HIV/HCV
B)

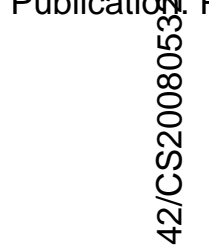

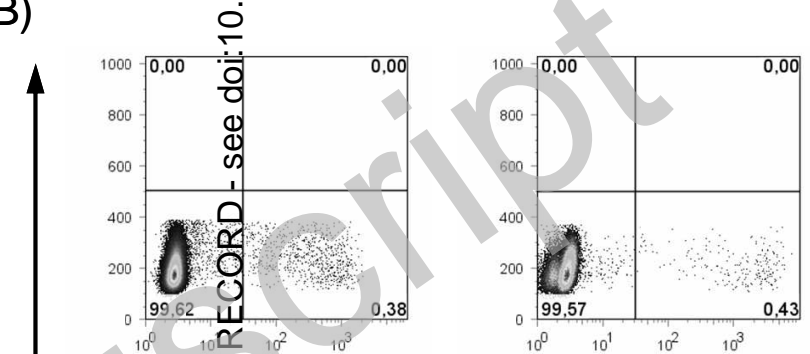

HCV

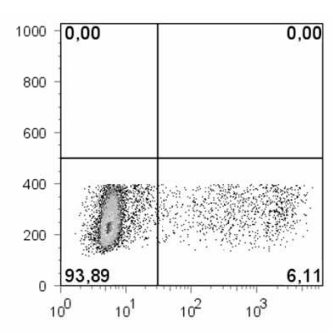

$\mathrm{HIV/HCV}$

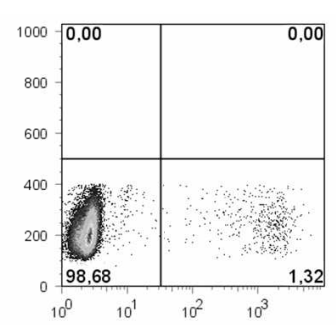

HIV/HCV 

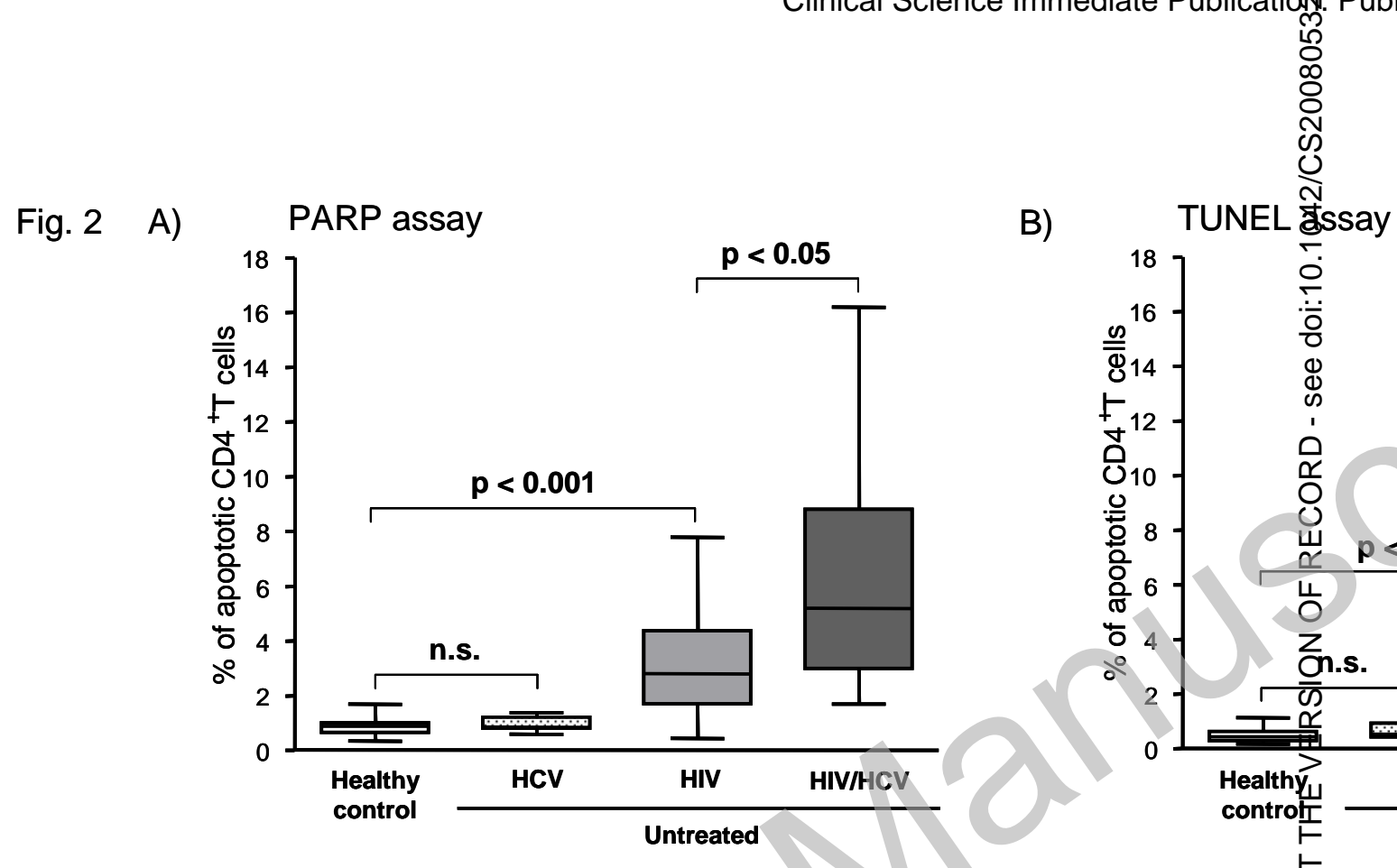

C)

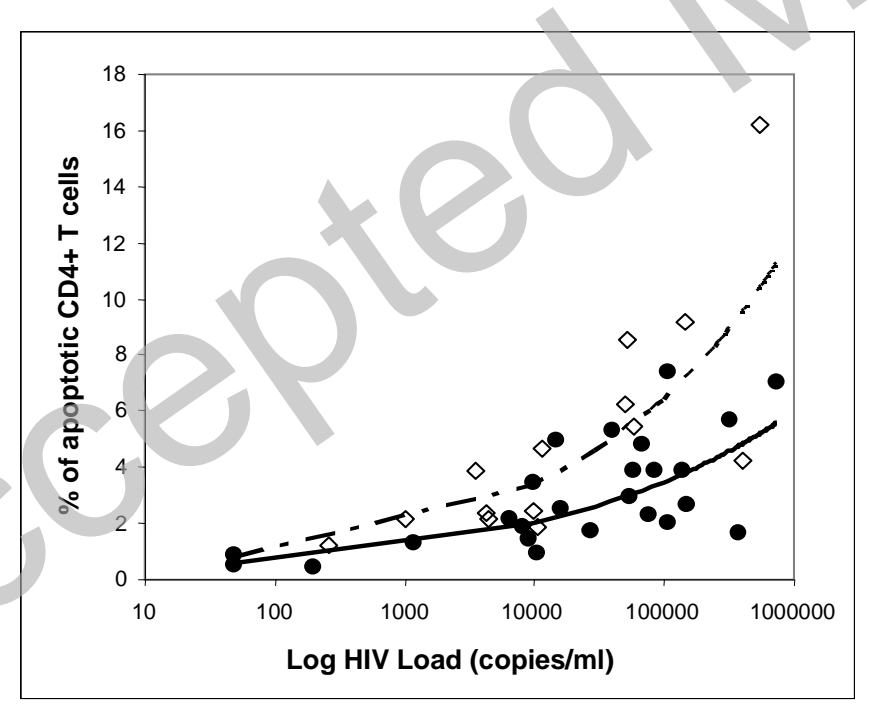

B) TUNEL ్ㅝㅀssay

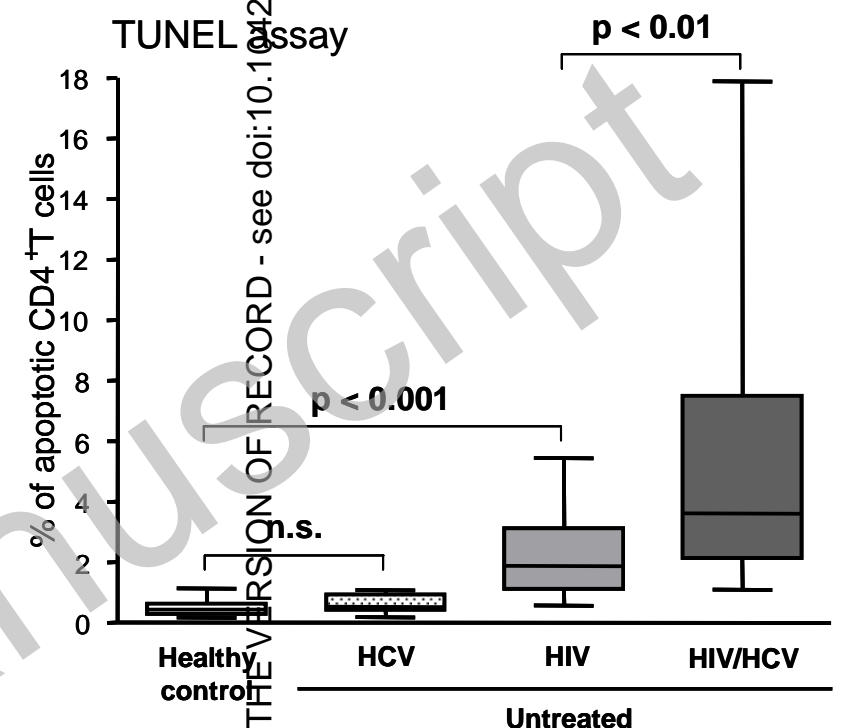

D)

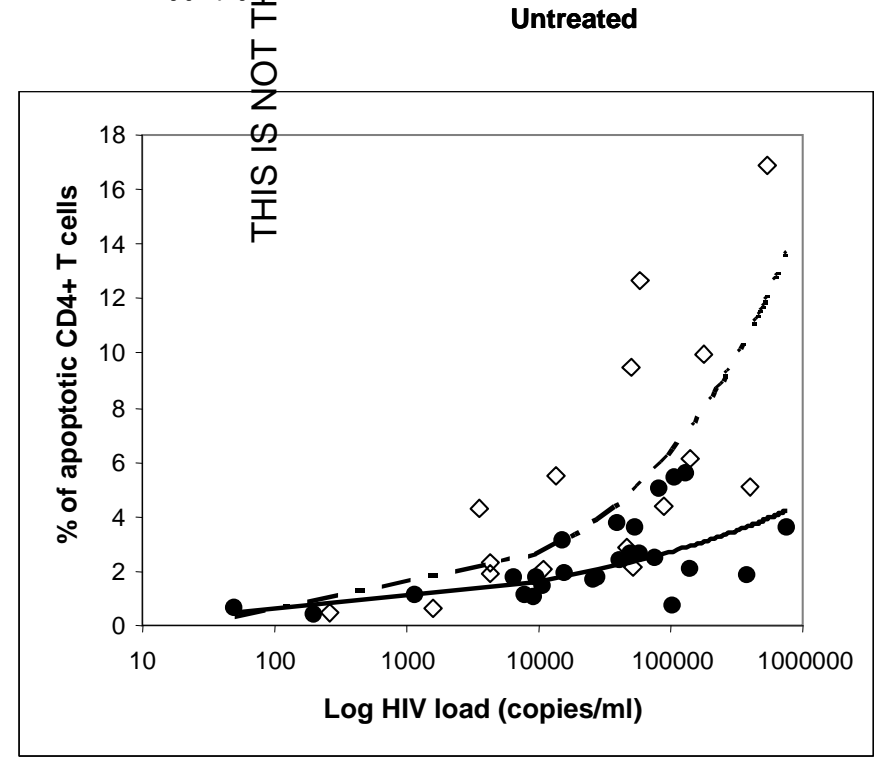


Fig. 3 A)

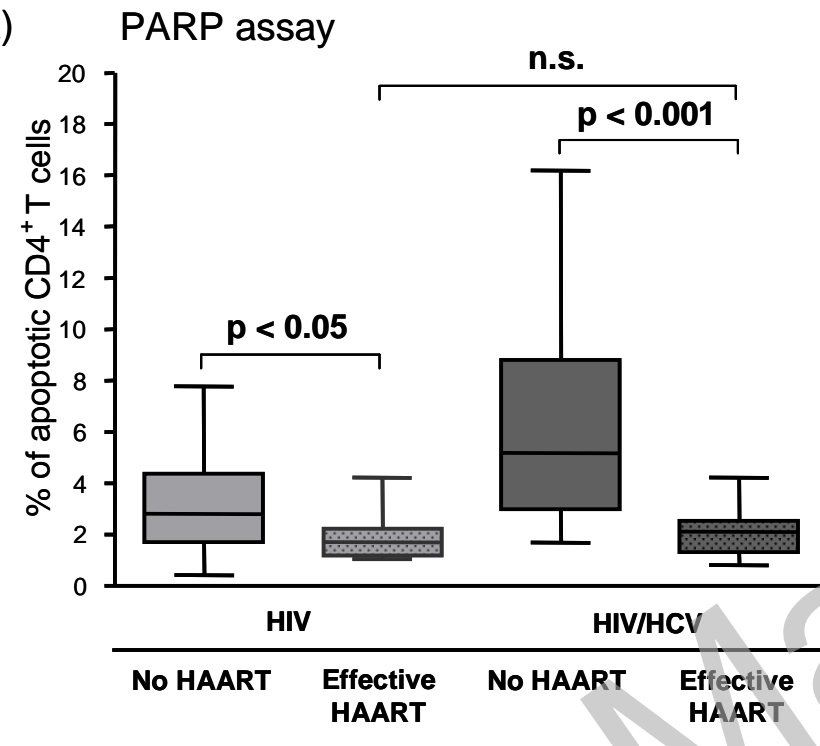

C)

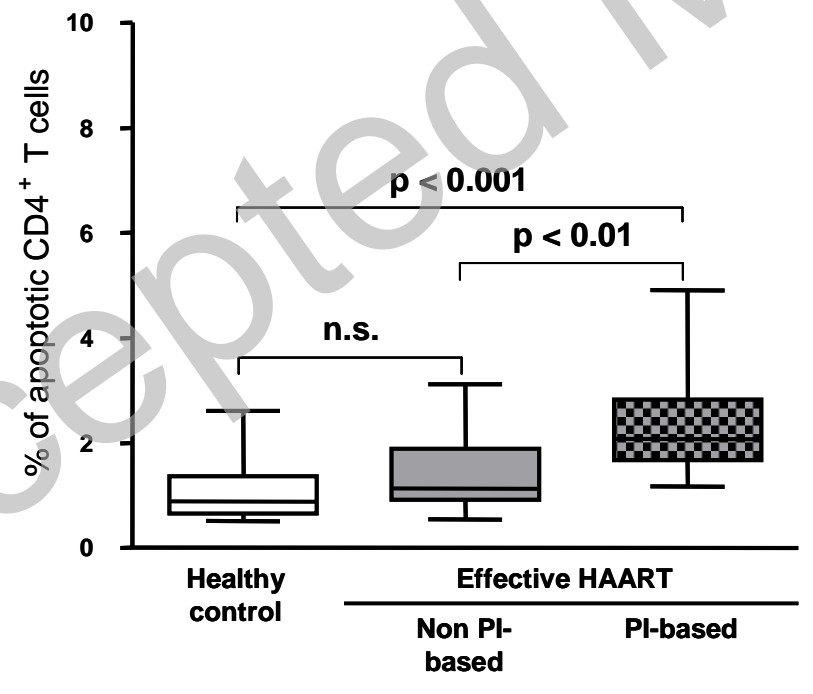

n.s.

B) TUNEL

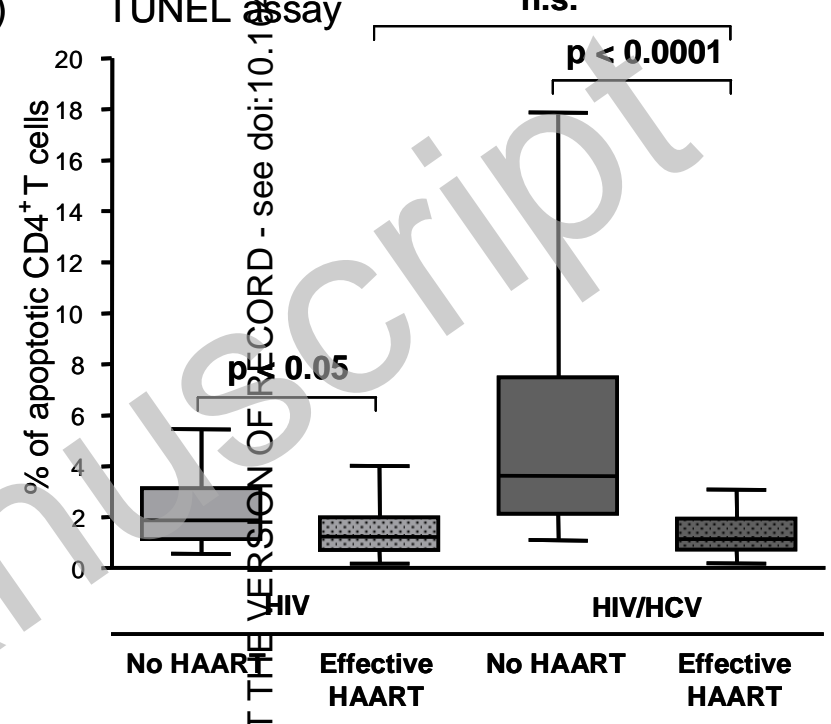

D)

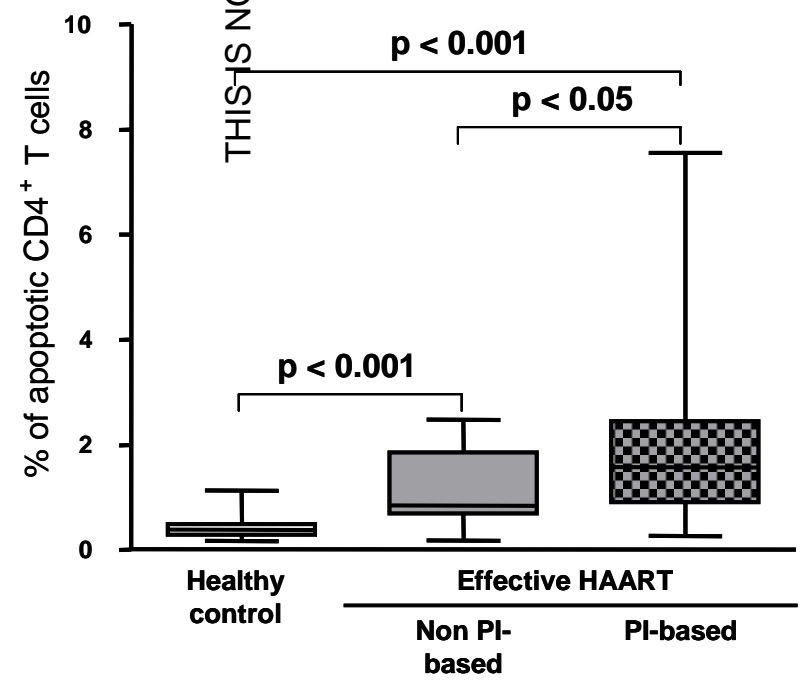


Fig. $4 \quad$ A)

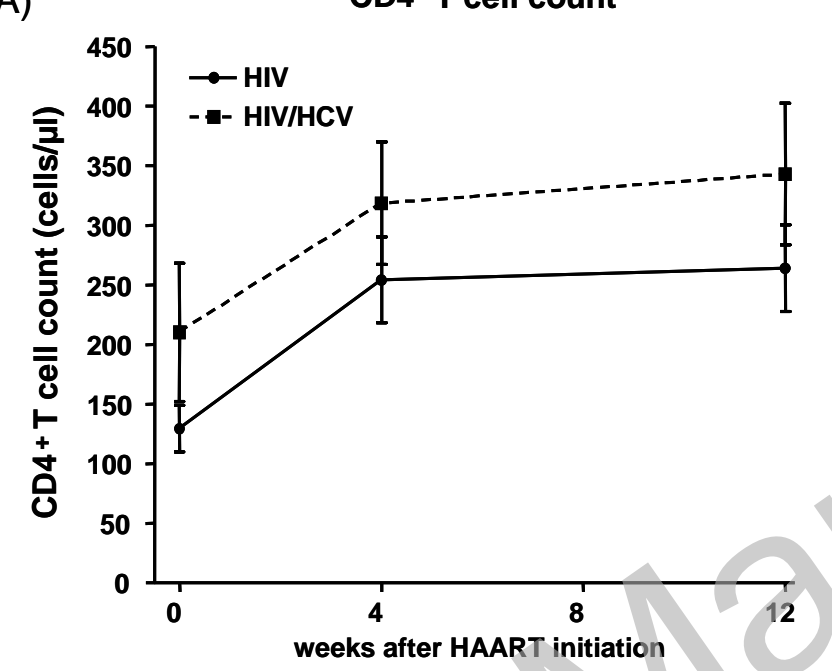

C)

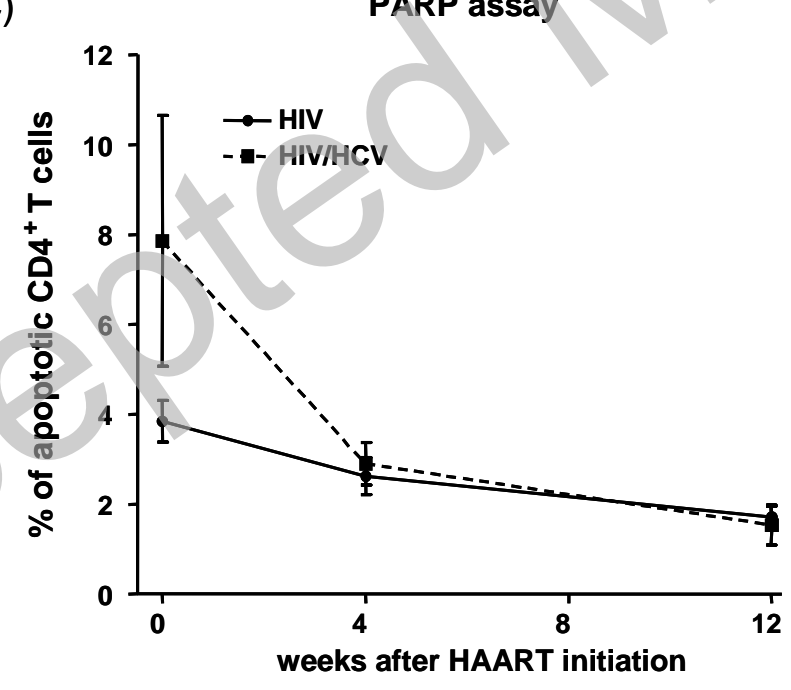

B)

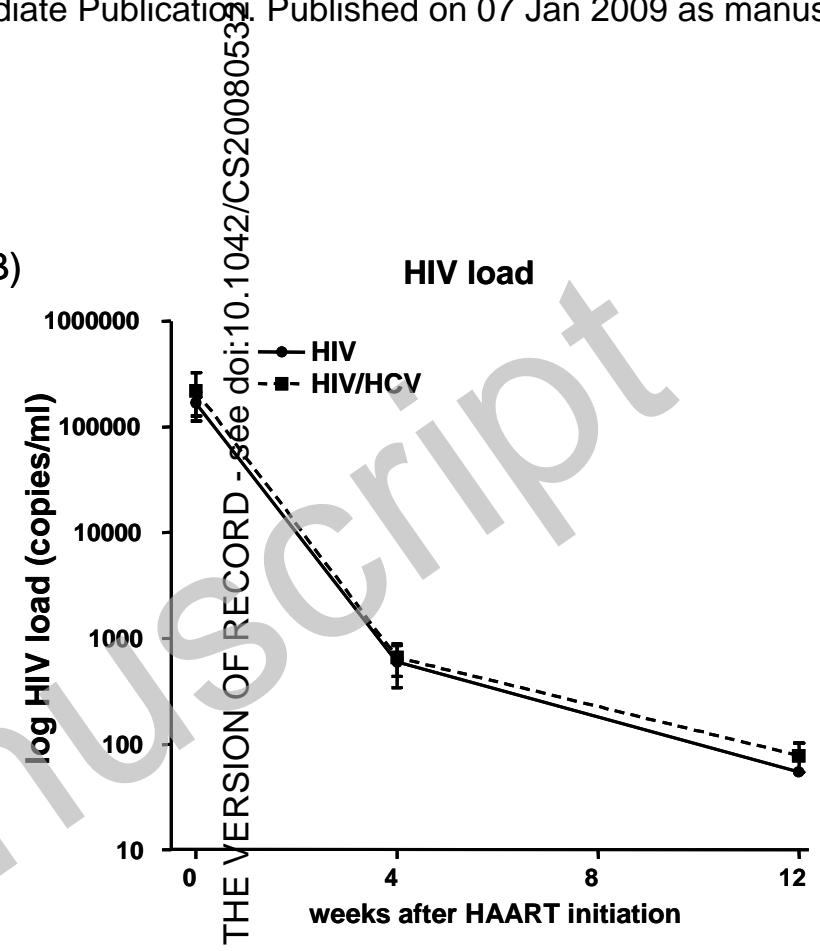

D)

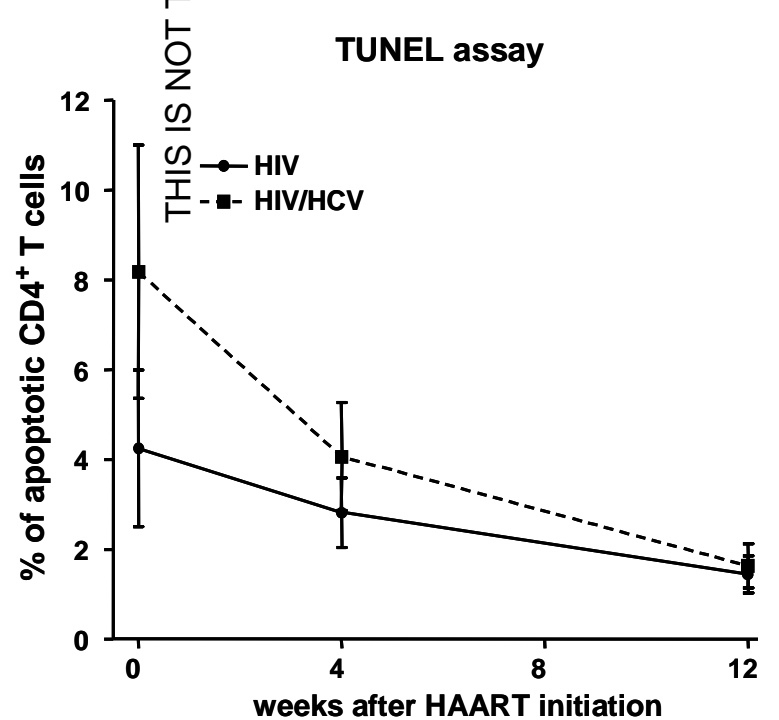

